\title{
Feasibility of using polypropylene ground cover upon consideration of long-term responses of sweet cherry nutrition and profitability
}

\author{
Xinhua Yin $^{1^{*}}$, Clark F. Seavert ${ }^{2}$ \\ ${ }^{1}$ Department of Plant Sciences, The University of Tennessee, Jackson, USA; \\ *Corresponding Author: xyin2@utk.edu \\ ${ }^{2}$ Department of Agricultural and Resource Economics, Ballard Extension Hall, Oregon State University, Corvallis, USA
}

Received 10 March 2012; revised 27 April 2012; accepted 12 May 2012

\section{ABSTRACT}

The impacts of synthetic polypropylene ground cover in the row area of sweet cherry (Prunus avium L.) trees ("Regina"|"Gisela 6") on soil nutrient availability, tree mineral nutrition and productivity, and economic returns were investigated on a Van Horn fine sandy loam soil at Hood River OR, from 2000 to 2007. Treatments included 2.44-m wide synthetic fabric ground cover made of black, woven polypropylene over the row area of cherry trees (woven fabric), and no ground cover but with herbicide applications in the row area with the same width as the polypropylene ground cover (herbicide strip)—standard industry practice. This article reports the plant nutrition and soil fertility results of 2006 and 2007 and profitability and feasibility results of 2000 to 2007. Tree leaf nitrogen (N) concentrations were significantly higher with $9 \%$ to $14 \%$ increases using woven fabric compared with herbicide strip in 2006 and 2007. Leaf sulfur (S) concentrations were also significantly increased with woven fabric in the two seasons. Woven fabric resulted in fruit with comparable quality and possible greater storability under enhanced fruit yields than herbicide strip in both years. Woven fabric was more profitable than herbicide strip based on an additional net present value of $\$ 2606 \mathrm{ha}^{-1}$ by the end of this study. Woven fabric had annual gross returns greater than annual costs in the fourth year after planting by $\$ 8181$ $\mathrm{ha}^{-1}$ relative to herbicide strip, and had cumulative net returns greater than total costs of all previous years in the sixth year after planting by $\$ 17,796 \mathrm{ha}^{-1}$ over herbicide strip. However, to establish a sweet cherry orchard with woven fabric, the grower would spend an additional \$4332 $\mathrm{ha}^{-1}$ over herbicide strip. In conclusion, woven fabric is a profitable and sustainable in-row ground management alternative to herbicide strip for orchards from a long-term perspective.

Keywords: Polypropylene Ground Cover; Sweet Cherry; Leaf Nutrition; Fruit Storability; Annual Gross Returns; Annual Cost; Annual Net Returns; Cumulative Net Returns; Present Value

\section{INTRODUCTION}

Ground management plays a key role in increasing the profitability and sustainability of tree fruit production [1, 2]. Effective ground management can control weeds, conserve soil moisture, prevent soil erosion, improve soil water infiltration and nutrient retention, enhance fruit quality, and maintain or improve soil organic matter and structure [3-5]. For decades, herbicide application in tree rows with grass alleys between tree rows has been the standard orchard ground management practice in the United States [6]. This system aims at providing a vegetation free zone within the tree rows to minimize weed competition with trees for water and nutrients, while maintaining soil structure in the alleys [7]. Although inrow herbicide application in orchards is effective in weed control, it is costly and has shown adverse effects on soil ecosystems and the environment $[8,9]$. For instance, herbicide application in the row area of orchards can reduce soil microbial activities [8,9] and elevate herbicide contamination of underground and surface water. Therefore, alternate in-row ground management practice needs to be explored in order to increase sustainability and profitability.

The uses of synthetic polypropylene, compost, crop straw, and wooden chips to cover the row area beneath orchard trees are emerging as in-row ground management alternatives to the traditional practice of herbicide applications. Mäge [10] has demonstrated that polypro- 
pylene ground cover could not only control weeds, but also reduce soil water evaporation. Reduced soil water evaporation generally increased soil moisture [10]; soil aeration may be reduced under some circumstances because of increased soil moisture content and the existence of a physical barrier provided by the polypropylene cover on the soil surface. All these factors could exert significant impacts on nutrient availability in soil and nutrient uptake by tree roots [11]. Neilsen [12] reported that the responses of apple leaf nutrient concentrations to polypropylene ground cover were nutrient specific and varied with growing season; apple tree vigor and yield were greater with polypropylene ground cover than no cover maintained by herbicide application in a six-year study in western Canada. The use of polypropylene ground cover has been reported to be suitable for young orchards growing on poor soils [13]. However, polypropylene ground cover does not allow organic matter inputs to soil which may have long-term soil quality implications [14].

Overall, more information is needed on the feasibility of using synthetic polypropylene ground cover in Pacific Northwest tree fruit production systems. Particularly, limited research on polypropylene ground cover has been conducted for sweet cherry. The objectives of this study were to 1) examine the long-term effects of synthetic polypropylene ground cover in the tree row area on soil nutrient availability, leaf nutrition of young sweet cherry, and economic returns; and 2) evaluate the long-term impacts of synthetic polypropylene ground cover in the row area on soil moisture and temperature, and the growth, yield, and quality of young sweet cherry. This publication mainly reports the results relevant to the first objective.

\section{MATERIALS AND METHODS}

\subsection{Site Description and Experimental Design}

A study on the use of synthetic polypropylene ground cover for sweet cherry was conducted on a Van Horn fine sandy loam soil (Fine-loamy, mixed, superactive, mesic Ultic Argixerolls) at the Mid-Columbia Agricultural Research and Extension Center of Oregon State University, Hood River, Oregon from 2000 through 2007. The Van Horn series consists of well drained soils on uplands and is a major soil type used for sweet cherry production in the region. These soils formed in stratified alluvial deposits, and they are moderately permeable. The 1.2-ha orchard used in this study was planted at $5.4 \mathrm{~m}$ between rows and $3 \mathrm{~m}$ within rows in March 2001 with secondleaf "Regina"/"Gisela 6" sweet cherry. The trees were trained to central leaders.

A randomized complete block design was used with two treatments and eight replicates in this study. One treatment was 2.44-m wide synthetic fabric, made of black woven polypropylene (DeWitt Co., Sikeston, MO), centered on the tree row (woven fabric). This waterpermeable polypropylene was placed on the ground in April 2001 with $30-\mathrm{cm}$ wide edges buried in the soil on both sides of a tree row; the polypropylene cover is supposed to last for 10 years in orchards. The other treatment was the control (no ground cover, but with herbicide applications in the row area of same width to control weeds) (herbicide strip). Roundup [N-(phosphonomethyl) glycine] at $1.4 \mathrm{~L} \cdot \mathrm{ha}^{-1}$ mixed with 147 liters $\mathrm{ha}^{-1}$ of water was sprayed in the control treatment in early June each year from 2001 to 2007 , and the weeds were well controlled. The control treatment is a normal industry practice for ground management. Each plot had 36 trees (including 3 "Sam" pollinizers and 1 "Attica" pollinizer) in four consecutive rows. Only the middle 12 trees in the two central rows were used for data collection to avoid border trees which may be affected by other treatments in the adjacent rows. Fertilizer recommendations were based on shoot growth and nutrient concentrations in leaf and soil. No nitrogen $(\mathrm{N})$, phosphorus $(\mathrm{P})$, or potassium (K) fertilizer was applied to either treatment during the first three years of the study. However, $\mathrm{N}$ fertilizer was broadcast on the top of woven fabric or the soil surface for both treatments in April at $8 \mathrm{~kg} \cdot \mathrm{N} \cdot \mathrm{ha}^{-1}$ in 2004 and $33 \mathrm{~kg} \cdot \mathrm{N} \cdot \mathrm{ha}^{-1}$ in 2005, 2006, and 2007 as ammonium sulfate based on the results of leaf and soil $\mathrm{N}$ tests and the Ore- gon State University fertilizer recommendations. Irrigation was conducted separately for each individual plot on a weekly basis from May to September according to tree needs in relation to soil moisture. Soil moisture content was measured weekly from May to September with a portable frequency domain reflectometry probe (Diviner 2000, Sentek, Australia) from 2001 to 2004 and from 2006 to 2007, but using a neutron probe (model CPN 503) in 2005.

\subsection{Soil and Plant Sampling and Analysis}

Soil sampling was conducted at the depth interval of 0 to $30 \mathrm{~cm}$ for each plot in October 2000 before tree planting and treatment imposition, and in August of 2006 and 2007. Ten soil cores per sample were collected from random locations approximately about half way to the drip line within each plot with a $2.5-\mathrm{cm}$ diameter soil probe. All samples were air dried, ground to pass through a 2-mm sieve, and thoroughly mixed. Soil available $\mathrm{NH}_{4}^{+}$, $\mathrm{NO}_{3}^{-}, \mathrm{P}, \mathrm{K}, \mathrm{Ca}, \mathrm{Mg}, \mathrm{S}, \mathrm{B}, \mathrm{Zn}, \mathrm{Mn}$, and $\mathrm{Cu}$ contents were extracted using the Mehlich III method [15]. Soil amino sugar $\mathrm{N}$ was extracted with $\mathrm{NaOH}$ [16]. Soil total $\mathrm{N}$ was determined by combustion [17]. Soil $\mathrm{pH}$ was determined in a 1:1 (soil: $\left.\mathrm{H}_{2} \mathrm{O}\right)$ solution [18], and organic matter was measured using the loss-on-ignition method [19]. 
A leaf sample was taken randomly from each plot in August of 2006 and 2007, respectively. Each leaf sample contained 24 newly but fully developed mid-terminal leaves from current year shoots at $1.5-\mathrm{m}$ level in the tree canopy. All these leaf samples were cleaned, oven-dried at $65^{\circ} \mathrm{C}$, and ground to pass through a $1-\mathrm{mm}$ sieve. Total $\mathrm{N}$ was determined using a combustion method with a Carlo Erba 1500 series Nitrogen/Carbon Analyzer [17]. Total P, K, Ca, Mg, S, B, Zn, Mn, and $\mathrm{Cu}$ were digested in a CEM MDS 2100 series microwave using nitric acid and hydrogen peroxide, and the digest was analyzed on a Thermo Jarrel Ash 1100 ICP [17].

\subsection{Fruit Quality and Storability}

Fruit quality was evaluated on an individual plot basis each year. Fruit sugar (brix) was determined using a PR101 $\alpha$ digital refractometer (Atago Co. LTD., Tokyo, Japan). Fruit firmness and size were assessed using 30 fruit per plot on a FirmTech 2 Fruit Firmness Tester (BioWorks Inc, Stillworks, OK). Visual evaluation of fruit surface pitting was conducted after the fruit had been stored in a cold storage room at $-1^{\circ} \mathrm{C}$ for three weeks in 2006 and 2007. Percentages of surface pitting associated with the four categories of excellent, slightly pitted, pitted, and bruised fruit were used in this evaluation.

\subsection{Economic Analysis}

Annual gross returns and cash costs for each orchard establishment year-including land preparation (ripping, disking, root removal, and fumigation), tree purchase and planting, purchasing and installation of woven fabric, tree pruning, mowing, control of weeds, diseases, and insects, irrigation, fertilization, and fruit harvest-were recorded each year from 2000 through 2007. A return to the grower price of $\$ 2.20$ per $\mathrm{kg}$ - a typical value averaged over fruit size and quality was used for the sale of sweet cherries each year [20]. Annual and cumulative net returns were calculated as the differences between annual gross returns and annual costs, and between cumulative gross returns and cumulative costs, respectively, for a designated year. The annual net returns were discounted using an $8 \%$ discount rate according to farming operation and its risk bearing ability for farms of medium size.

In this study, profitability is calculated by the net present value of the stream of net returns of each treatment over time. Profitability determines if the grower can make money by investing in woven fabric as opposed to herbicide strip. Feasibility is expressed as 1) the year in which annual gross returns are greater than annual costs (cash flow), 2) the year cumulative returns are greater than total costs of all previous years (breakeven year), and 3) the total funds required to establish a sweet cherry orchard utilizing woven fabric. The feasibility deter- mines if the grower can afford to invest in woven fabric. These profitability and feasibility definitions are the standards that are commonly used in the region. The profitability and feasibility in this study was calculated using the Agriculture's Profitability Tool computer software model [21].

\subsection{Statistical Analysis}

Analysis of variance (ANOVA) for each variable was conducted separately each year because of the heterogeneous errors across years using the ANOVA procedure in the SAS package (SAS Institute, Cary, NC). Analysis of variance was performed on each variable as a randomized complete block design with two treatments, replicated eight times. Probability levels less than 0.05 were designated as significant.

This report focuses on the analysis of annual net returns, cumulative net returns, and present value for the entire study period from 2000 to 2007 . Since the results about plant nutrition, soil fertility, cash costs, and gross returns of 2000 through 2005 have been published in Yin et al. [22], this article reports the results of the above measurements obtained from 2006 and 2007.

\section{RESULTS AND DISCUSSION}

\subsection{Woven Fabric Effects on Leaf Nutrition}

Woven fabric exerted significant effects on leaf $\mathrm{N}$ concentrations in both 2006 and 2007 (Table 1). Leaf N levels in August, about one month after fruit harvest, were $14 \%$ and $9 \%$ greater with woven fabric than herbicide strip in 2006 and 2007, respectively.

Although the leaf $\mathrm{N}$ results of 2006 and 2007 showed the same trend as those of most previous years (2002 to 2005 ) when leaf $\mathrm{N}$ concentrations were $11 \%$ to $19 \%$ greater with woven fabric than herbicide strip [22], the magnitude of differences in leaf $\mathrm{N}$ levels between the two treatments seemed to diminish in 2006 and 2007. This phenomenon indicates that $\mathrm{N}$ fertilizer applications in 2006 and 2007 may not be adequate for the trees in the woven fabric treatment which significantly outyielded the trees with herbicide strip.

Previous research has shown that leaf $\mathrm{N}$ concentrations are indicative of $\mathrm{N}$ nutrition status of bearing sweet cherry trees. Leaf nutrient concentrations in August, approximately one month after fruit harvest, are commonly used as references to evaluate the nutrient management program implemented in the present season, and to make fertilizer recommendations for the coming season in the Mid-Columbia region, Oregon, and other regions in the Pacific northwestern U.S. Total N concentration of below $17 \mathrm{~g} \cdot \mathrm{kg}^{-1}$ on a dry leaf weight basis is generally considered deficient for optimum tree growth and fruit production of sweet cherry [23]. Average leaf $\mathrm{N}$ 
Table 1. Leaf N, P, K, Ca, Mg, and S concentrations (dry-weight basis) of "Regina"/“Gisela 6" sweet cherry as affected by woven fabric relative to herbicide strip, 2006-2007.

\begin{tabular}{cccccccccccccc}
\hline Year & Treatment & $\begin{array}{c}\mathrm{N} \\
\mathrm{g} \cdot \mathrm{kg}^{-1}\end{array}$ & $\begin{array}{c}\mathrm{SD} \\
\mathrm{g} \cdot \mathrm{kg}^{-1}\end{array}$ & $\begin{array}{c}\mathrm{P} \cdot \mathrm{kg}^{-1} \\
\mathrm{2} 2006\end{array}$ & $\begin{array}{c}\mathrm{SD} \\
\mathrm{g} \cdot \mathrm{kg}^{-1}\end{array}$ & $\begin{array}{c}\mathrm{K} \\
\mathrm{g} \cdot \mathrm{kg}^{-1}\end{array}$ & $\begin{array}{c}\text { SD } \\
\mathrm{g} \cdot \mathrm{kg}^{-1}\end{array}$ & $\begin{array}{c}\mathrm{Ca} \\
\mathrm{g} \cdot \mathrm{kg}^{-1}\end{array}$ & $\begin{array}{c}\text { SD } \\
\mathrm{g} \cdot \mathrm{kg}^{-1}\end{array}$ & $\begin{array}{c}\mathrm{Mg} \\
\mathrm{g} \cdot \mathrm{kg}^{-1}\end{array}$ & $\begin{array}{c}\text { SD } \\
\mathrm{g} \cdot \mathrm{kg}^{-1}\end{array}$ & $\begin{array}{c}\text { S } \\
\mathrm{g} \cdot \mathrm{kg}^{-1}\end{array}$ & $\begin{array}{c}\text { SD } \\
\mathrm{g} \cdot \mathrm{kg}^{-1}\end{array}$ \\
& Herbicide strip & $18.9 \mathrm{~b}$ & 0.14 & $2.4 \mathrm{a}$ & 0.02 & $20.6 \mathrm{~b}$ & 0.03 & $16.1 \mathrm{a}$ & 0.18 & $4.4 \mathrm{a}$ & 0.02 & $1.3 \mathrm{~b}$ & 0.01 \\
\multirow{2}{*}{2007} & Woven fabric & $21.5 \mathrm{a}$ & 0.09 & $2.5 \mathrm{a}$ & 0.02 & $21.8 \mathrm{a}$ & 0.12 & $16.0 \mathrm{a}$ & 0.16 & $4.2 \mathrm{a}$ & 0.03 & $1.4 \mathrm{a}$ & 0.01 \\
& Herbicide strip & $20.6 \mathrm{~b}$ & 0.17 & $3.0 \mathrm{a}$ & 0.04 & $23.5 \mathrm{a}$ & 0.12 & $13.1 \mathrm{a}$ & 0.13 & $3.6 \mathrm{a}$ & 0.02 & $1.1 \mathrm{~b}$ & 0.01 \\
& Woven fabric & $22.4 \mathrm{a}$ & 0.12 & $2.9 \mathrm{a}$ & 0.03 & $23.9 \mathrm{a}$ & 0.06 & $12.5 \mathrm{a}$ & 0.14 & $3.6 \mathrm{a}$ & 0.03 & $1.2 \mathrm{a}$ & 0.01 \\
\hline
\end{tabular}

Notes: SD: standard deviation. Values in column within each year followed by the same letter are not significantly different at $5 \%$ probability level.

concentrations under both treatments in this study ranged from 18.9 to $22.4 \mathrm{~g} \cdot \mathrm{kg}^{-1}$ in both 2006 and 2007 , all well above the threshold of deficiency, and were considered adequate. In addition, no visual $\mathrm{N}$ deficiency symptoms were observed in any treatment in either year.

Our results are in general different from those in western Canada [12] in that no significant differences in leaf $\mathrm{N}$ concentrations were observed on apple trees between in-row woven fabric and herbicide application from 1994 to 1999. Insignificant differences observed in the study of Nielsen et al. [12] were likely due to the fact that $\mathrm{N}$ was fertigated, which probably negated the woven fabric effect on leaf $\mathrm{N}$ relative to the control. Based on the findings of Nielsen et al. [12], the effects of woven fabric on leaf $\mathrm{N}$ concentrations would have been negated if $\mathrm{N}$ application rates had been higher in our study.

Similar to leaf $\mathrm{N}$, leaf $\mathrm{S}$ concentrations were $8 \%$ and 9\% greater in 2006 and 2007, respectively, with woven fabric relative to herbicide strip (Table 1). Leaf S concentration of 2.0 to $4.0 \mathrm{~g} \cdot \mathrm{kg}^{-1}$ on a dry leaf weight basis are generally considered adequate for optimum tree growth and fruit production of sweet cherry [24]. Average leaf $\mathrm{S}$ concentrations under both treatments in this study were in a range of 1.1 to $1.4 \mathrm{~g} \cdot \mathrm{kg}^{-1}$ in both years, all well below the threshold of sufficiency, and were considered deficiency. However, no visual $\mathrm{S}$ deficiency symptoms were observed in any treatment in either year. In addition, leaf $\mathrm{Cu}$ concentrations were $16 \%$ greater under woven fabric compared with herbicide strip in 2006 (Table 2). However, no differences in leaf B, Zn, or Mn were observed between the two treatments regardless of year (Table 2).

The results of both years in this study suggest that leaf nutrient concentrations respond differentially to woven fabric. The total uptake of N, P, K, Ca, Mg, S, B, Zn, Mn, or $\mathrm{Cu}$ per tree per year seems to be markedly increased under woven fabric compared with herbicide strip due to an over $30 \%$ increase in both tree growth and fruit yield in the woven fabric treatment. The enhanced uptake of nutrients from soil under woven fabric may be attributed to the larger soil volume penetrated by root systems of woven fabric-covered trees, elevated soil moisture and temperature beneath woven fabric, or/and reduced com- petition for nutrients from weeds under woven fabric [25]. Higher rates of fertilizers may need to be applied to woven fabric-covered trees due to enhanced tree growth and productivity over the long run.

\subsection{Woven Fabric Effects on Fruit Quality and Storability}

Pitting in sweet cherries are small sunken areas on fruit surface. Symptoms are primarily resultant from a mechanical impact or compression [26]. Pitting is associated with physical damage to cell near the epidermis which collapse over time. Sweet cherry pitting becomes apparent after fruit is stored for several days at room temperatures or longer at lower temperatures. Physical damage on sweet cherry fruit can occur during fruit picking, packing, and transportation [27]. Overall, surface pitting has long been a very common and major problem in the fresh market sweet cherry industry in the Pacific Northwest. It is one of the leading causes of product rejection and price reductions from the fresh market.

Fruit quality attributes, including sugar content, and firmness, generally did not differ between the two treatments (Table 3). However, fruit size was greater with woven fabric than herbicide strip in 2007. Fruit surface pitting evaluation showed that woven fabric increased marketable fruit (excellent fruit + slightly pitted fruit) by 8\% (absolute value) via reducing fruit pitting in 2006 (Table 3). Our results showed that beneficial effects of woven fabric on fruit size and surface pitting are not consistent with years. In addition, fruit sugar, firmness, and size in 2006 seemed to be lower than those in 2007 in both treatments. All these variations between the two years may be related to the differences in management practices such as tree pruning and irrigation and weather conditions during the season.

\subsection{Woven Fabric Effects on Soil Nutrient Availability}

The soil $\mathrm{pH}$ after fruit harvest was lower for woven fabric relative to herbicide strip in 2006 and 2007 (Table 4). No significant difference in soil organic matter was observed between the two treatments regardless of year 
Table 2. Leaf B, Zn, Mn, and Cu concentrations (dry-weight basis) of "Regina"/"Gisela 6" sweet cherry as affected by woven fabric relative to herbicide strip, 2006-2007.

\begin{tabular}{cccccccccc}
\hline Year & Treatment & $\begin{array}{c}\mathrm{B} \\
\mathrm{mg} \cdot \mathrm{kg}^{-1}\end{array}$ & $\begin{array}{c}\mathrm{SD} \\
\mathrm{mg} \cdot \mathrm{kg}^{-1}\end{array}$ & $\begin{array}{c}\mathrm{Zn} \\
\mathrm{mg} \cdot \mathrm{kg}^{-1}\end{array}$ & $\begin{array}{c}\mathrm{SD} \\
\mathrm{mg} \cdot \mathrm{kg}^{-1}\end{array}$ & $\begin{array}{c}\mathrm{Mn} \\
\mathrm{mg} \cdot \mathrm{kg}^{-1}\end{array}$ & $\begin{array}{c}\mathrm{SD} \\
\mathrm{mg} \cdot \mathrm{kg}^{-1}\end{array}$ & $\begin{array}{c}\mathrm{Cu} \\
\mathrm{mg} \cdot \mathrm{kg}^{-1}\end{array}$ & $\begin{array}{c}\mathrm{SD} \\
\mathrm{mg} \cdot \mathrm{kg}^{-1}\end{array}$ \\
\hline \multirow{2}{*}{2006} & Herbicide strip & $63.9 \mathrm{a}$ & 4.56 & $12.6 \mathrm{a}$ & 1.06 & $45.0 \mathrm{a}$ & 9.1 & $4.5 \mathrm{~b}$ & 0.47 \\
& Woven fabric & $65.4 \mathrm{a}$ & 3.80 & $13.3 \mathrm{a}$ & 1.24 & $49.6 \mathrm{a}$ & 12.6 & $5.2 \mathrm{a}$ & 0.59 \\
& & & & & & & & & \\
\multirow{2}{*}{2007} & Herbicide strip & $60.9 \mathrm{a}$ & 2.86 & $9.2 \mathrm{a}$ & 1.09 & $37.1 \mathrm{a}$ & 5.6 & $5.1 \mathrm{a}$ & 0.37 \\
& Woven fabric & $62.4 \mathrm{a}$ & 2.41 & $9.7 \mathrm{a}$ & 0.74 & $39.2 \mathrm{a}$ & 8.8 & $5.5 \mathrm{a}$ & 0.68 \\
\hline
\end{tabular}

Note: SD: standard deviation. Values in column within each year followed by the same letter are not significantly different at $5 \%$ probability level.

Table 3. Fruit quality and surface pitting of "Regina"/“Gisela 6" sweet cherry as affected by woven fabric relative to herbicide strip, 2006-2007.

\begin{tabular}{|c|c|c|c|c|c|c|c|c|c|}
\hline Year & Treatment & $\begin{array}{l}\text { Sugar } \\
\text { (brix) }\end{array}$ & $\begin{array}{l}\text { Firmness } \\
\left(\mathrm{g} \cdot \mathrm{mm}^{-2}\right)\end{array}$ & $\begin{array}{l}\text { Size } \\
(\mathrm{mm})\end{array}$ & $\begin{array}{c}\text { Excellent } \\
(\%)\end{array}$ & $\begin{array}{c}\text { Slightly pitted } \\
(\%)\end{array}$ & $\begin{array}{c}\text { Excellent }+ \\
\text { slightly pitted } \\
(\%)\end{array}$ & $\begin{array}{l}\text { Pitted } \\
(\%)\end{array}$ & $\begin{array}{c}\text { Bruised } \\
(\%)\end{array}$ \\
\hline \multirow[t]{2}{*}{2006} & Herbicide strip & $19.2 \mathrm{a}$ & $245.5 a$ & $26.2 \mathrm{a}$ & $32.4 b$ & $31.3 \mathrm{a}$ & $63.8 b$ & $27.2 \mathrm{a}$ & $9.0 \mathrm{a}$ \\
\hline & Woven fabric & $19.6 \mathrm{a}$ & $245.6 \mathrm{a}$ & $25.9 \mathrm{a}$ & $43.7 \mathrm{a}$ & $29.7 \mathrm{a}$ & $71.6 \mathrm{a}$ & $18.5 b$ & $9.9 \mathrm{a}$ \\
\hline \multirow[t]{2}{*}{2007} & Herbicide strip & $23.8 \mathrm{a}$ & $286.1 \mathrm{a}$ & $27.7 b$ & $44.6 \mathrm{a}$ & $26.8 \mathrm{a}$ & $71.4 \mathrm{a}$ & $23.8 \mathrm{a}$ & $4.8 \mathrm{~b}$ \\
\hline & Woven fabric & $23.3 \mathrm{a}$ & $288.6 \mathrm{a}$ & $28.2 \mathrm{a}$ & $45.9 \mathrm{a}$ & $26.5 \mathrm{a}$ & $72.4 \mathrm{a}$ & $20.2 \mathrm{a}$ & $7.4 \mathrm{a}$ \\
\hline
\end{tabular}

Note: Values in column within each year followed by the same letter are not significantly different at $5 \%$ probability level.

Table 4. Soil $\mathrm{pH}$, organic matter $(\mathrm{OM})$, total $\mathrm{N}$, amino sugar $\mathrm{N}, \mathrm{NH}_{4}^{+}-\mathrm{N}, \mathrm{NO}_{3}^{-}-\mathrm{N}, \mathrm{P}, \mathrm{K}, \mathrm{Ca}, \mathrm{Mg}, \mathrm{S}, \mathrm{B}, \mathrm{Zn}, \mathrm{Mn}$, and $\mathrm{Cu}$ contents in "Regina"/“Gisela 6" sweet cherry orchard as affected by woven fabric relative to herbicide strip, 2006-2007.

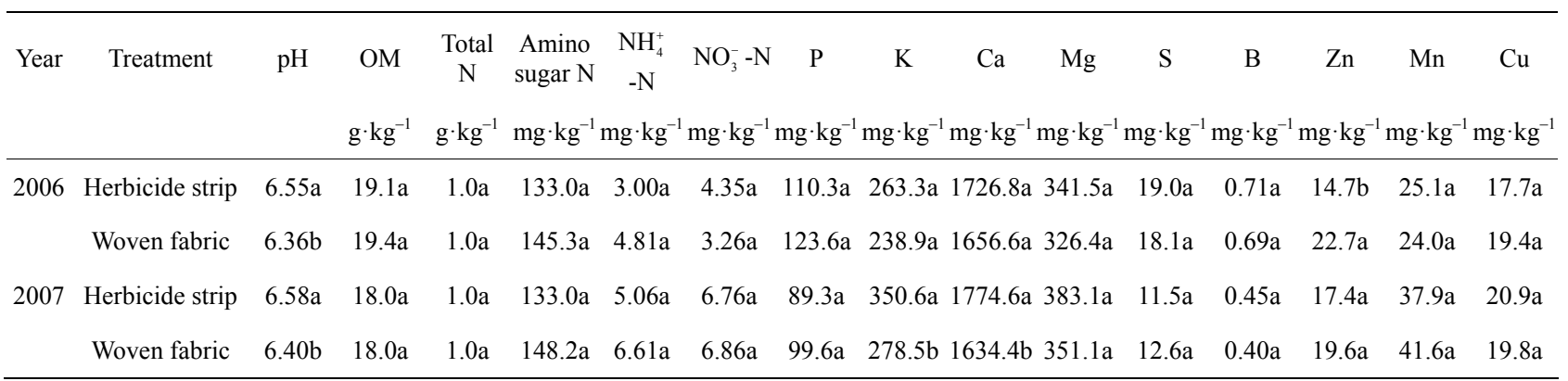

Note: Values in column within each year followed by the same letter are not significantly different at $5 \%$ probability level.

(Table 4), although woven fabric serves as a physical barrier to prevent organic matter additions to the soil. This trend might be attributed to the assumption that although tree leaves fall on the top of woven fabric, they could still be decomposed by soil microbes and washed down through the woven fabric and then down to the soil profile by rain and irrigation water.

Overall, soil under different treatments had similar available soil nutrient levels (except lower $\mathrm{K}$ and $\mathrm{Ca}$ in 2007) in 2006 and 2007, which were similar to those observed in the previous years, although woven fabric treatment produced remarkably higher fruit yields. Lower soil $\mathrm{K}$ and $\mathrm{Ca}$ contents with woven fabric in 2007 were within our expectation because the tree growth and fruit yield were significantly enhanced with woven fabric compared with herbicide strip during 2006 and 2007. Enhanced tree growth and fruit yield with woven fabric increased the removal of nutrients from soil, thus reducing the available nutrient levels in the soil.

It seemed there were some differences in soil $\mathrm{NH}_{4}^{+}-\mathrm{N}$, $\mathrm{NO}_{3}^{-}-\mathrm{N}, \mathrm{P}, \mathrm{K}, \mathrm{Mg}, \mathrm{S}, \mathrm{B}$, and $\mathrm{Mn}$ contents regardless of treatment between 2006 and 2007. Contents of soil $\mathrm{NH}_{4}^{+}-\mathrm{N}, \mathrm{NO}_{3}^{-}-\mathrm{N}, \mathrm{K}, \mathrm{Mg}$, and $\mathrm{Mn}$ were lower, but soil $\mathrm{P}$, $\mathrm{S}$, and B levels were higher, in both treatments in 2006 than those in 2007. The differences in management practices such as tree pruning and irrigation and weather conditions between the two years might have affected tree nutrient uptake from the soil, and thus resulted in variations in soil nutrient contents after fruit harvest between the two years. 


\subsection{Profitability and Feasibility of Woven Fabric}

There were no annual gross returns for either of the treatments during 2000 to 2003 because there was no fruit production in either treatment during that time (Table 5). After that, woven fabric had greater annual gross returns than herbicide strip each year. The increases in annual gross returns were $219 \%, 43 \%, 33 \%$, and $37 \%$ with woven fabric over herbicide strip in 2004-2007. Averaged over the four production seasons (2004 to 2007), woven fabric resulted in a $44 \%$ increase in annual gross returns over herbicide strip.

The annual cost was the same for both treatments in the first year (2000) since the costs in that year were from field preparation and tree planting, and were the same for both treatments (Table 5). After that, woven fabric had annual cost $37 \%,-1 \%, 0.3 \%, 93 \%, 38 \%, 30 \%$, and $26 \%$ greater than herbicide strip in 2001, 2002, 2003, 2004, 2005, 2006, and 2007, respectively. The purchase of woven fabric was the main cause for higher annual cost with woven fabric in 2001. More labor for tree pruning and training and fruit harvest due to greater tree growth and higher fruit yields associated with woven fabric was the main reason for higher annual cost for subsequent years.

Annual net returns were greater with woven fabric than herbicide strip in both 2006 and 2007 (Table 5). Woven fabric resulted in an increase of $34 \%(\$ 12,811$ $\mathrm{ha}^{-1}$ ) and $40 \%\left(\$ 4846 \mathrm{ha}^{-1}\right)$ in annual net returns over herbicide strip in 2006 and 2007, respectively (Table 5).

Table 5. Annual gross returns, annual cost, annual net returns, cumulative net returns, and present values of "Regina"/“Gisela 6" sweet cherry as affected by woven fabric relative to herbicide strip, 2000-2007.

\begin{tabular}{|c|c|c|c|c|c|c|}
\hline Year & Treatment & $\begin{array}{l}\text { Annual gross returns } \\
\qquad \$ \mathrm{ha}^{-1}\end{array}$ & $\begin{array}{l}\text { Annual cost } \\
\qquad \text { ha }^{-1}\end{array}$ & $\begin{array}{l}\text { Annual net returns } \\
\qquad \$ \mathrm{ha}^{-1}\end{array}$ & $\begin{array}{l}\text { Cumulative net returns } \\
\qquad \$ \text { ha }^{-1}\end{array}$ & $\begin{array}{l}\text { Present value } \\
\qquad \$ \mathrm{ha}^{-1}\end{array}$ \\
\hline \multirow[t]{3}{*}{2000} & Herbicide strip & 0 & 2456 & -2456 & -2456 & -2456 \\
\hline & Woven fabric & 0 & 2456 & -2456 & -2456 & -2456 \\
\hline & Significance & $\mathrm{ns} \dagger$ & ns & ns & ns & ns \\
\hline \multirow[t]{3}{*}{2001} & Herbicide strip & 0 & 11,944 & $-11,944$ & $-14,400$ & $-11,059$ \\
\hline & Woven fabric & 0 & 16,328 & $-16,328$ & $-18,784$ & $-15,119$ \\
\hline & Significance & ns & $* * *$ & $* * *$ & $* * *$ & $* * *$ \\
\hline \multirow[t]{3}{*}{2002} & Herbicide strip & 0 & 3960 & -3960 & $-18,360$ & -3395 \\
\hline & Woven fabric & 0 & 3906 & -3906 & $-22,690$ & -3349 \\
\hline & Significance & $\mathrm{ns}$ & $* * *$ & $* * *$ & $* * *$ & $* * *$ \\
\hline \multirow[t]{3}{*}{2003} & Herbicide strip & 0 & 788 & -788 & $-19,148$ & -626 \\
\hline & Woven fabric & 0 & 790 & -790 & $-23,480$ & -623 \\
\hline & Significance & ns & $* * *$ & $* * *$ & $* * *$ & $* * *$ \\
\hline \multirow[t]{3}{*}{2004} & Herbicide strip & 3743 & 2093 & 1650 & $-17,498$ & 1213 \\
\hline & Woven fabric & 11,924 & 4046 & 7878 & $-15,602$ & 5791 \\
\hline & Significance & $* * *$ & $* * *$ & $* * *$ & ns & $* * *$ \\
\hline \multirow[t]{3}{*}{2005} & Herbicide strip & 9363 & 2473 & 6890 & $-10,608$ & 4689 \\
\hline & Woven fabric & 13,394 & 3415 & 9979 & -5623 & 6792 \\
\hline & Significance & $* *$ & $* * *$ & $* *$ & $* *$ & $* *$ \\
\hline \multirow[t]{3}{*}{2006} & Herbicide strip & 46,914 & 9307 & 37,607 & 26,999 & 23,699 \\
\hline & Woven fabric & 62,518 & 12,100 & 50,418 & 44,795 & 31,772 \\
\hline & Significance & $* *$ & $* *$ & $* *$ & $* *$ & $* *$ \\
\hline \multirow[t]{3}{*}{2007} & Herbicide strip & 16,020 & 3948 & 12,072 & 39,071 & 7044 \\
\hline & Woven fabric & 21,910 & 4992 & 16,918 & 61,713 & 9871 \\
\hline & Significance & $*$ & $*$ & $*$ & $* * *$ & * \\
\hline
\end{tabular}

Note: ns not significant at the 0.05 probability level; ${ }^{* * *}$, and $^{* * *}$ significant at the $0.05,0.01$, and 0.001 probability levels, respectively. 
Greater annual gross returns from increased fruit yields with woven fabric offset higher labor costs for pruning and training the larger trees and harvesting higher fruit yields, and thus resulting in greater annual net returns. This trend was also observed in 2004 and 2005, the first two years with commercial fruit harvest [22].

The cumulative net returns for woven fabric were $30 \%$, $24 \%$, and $23 \%$ lower in 2001,2002 , and 2003, but were $11 \%, 47 \%, 66 \%$, and $58 \%$ greater than those with herbicide strip in 2004, 2005, 2006, and 2007 (Table 5), respectively. From 2000 to 2007, the cumulative net returns for woven fabric were $\$ 22,642 \mathrm{ha}^{-1}$ greater than those with herbi- cide strip.

The net present value differed between the two treatments every year except the first year of 2000 (Table 5). Beginning with 2004, the first year with commercial fruit harvest, both treatments had positive net present values, but woven fabric had greater net present value than herbicide strip each year. Woven fabric was more profitable by $\$ 13,566 \mathrm{ha}^{-1}$ based on the net present value by the end of this study (2007). Determining the profitability and feasibility of woven fabric in this study showed that a grower can obtain a higher net present value of cumulative net returns of $\$ 13,566 \mathrm{ha}^{-1}$ by the end of the seventh year by investing in woven fabric, but must also invest $\$ 4332 \mathrm{ha}^{-1}$ more during the first four years of establishing a sweet cherry orchard with woven fabric to receive that profit. Woven fabric is supposed to be persistent on the ground for 10 years.

Overall, both treatments began to have annual gross returns greater than annual costs in the fourth year after planting (2004). Woven fabric had annual net returns of $\$ 7878 \mathrm{ha}^{-1}$ and herbicide strip $\$ 1650 \mathrm{ha}^{-1}$ in 2004. Likewise, both treatments had cumulative net returns greater than total costs of all previous years beginning from the sixth year after planting (2006). However, woven fabric had generated $\$ 44,795 \mathrm{ha}^{-1}$ in cumulative net returns in 2006 and herbicide strip $\$ 26,999 \mathrm{ha}^{-1}$.

Although the results of this seven-year study demonstrated that woven fabric in the row areas of sweet cherry trees generally exerts beneficial effects on leaf mineral nutrition, fruit storability, and annual and cumulative net returns, integration of woven fabric into a tree fruit production system requires more knowledge and consideration of tree physiology (such as tree vigor), soil and climate type, grower preferences and resources, and local regulations concerning water and soil quality.

\section{CONCLUSION}

Leaf $\mathrm{N}$ and $\mathrm{S}$ concentrations were significantly enhanced with woven fabric compared with herbicide strip in 2006 and 2007, the sixth and seventh years of experimentation. Woven fabric produced fruit with comparable quality and possible greater storability under en- hanced fruit yields in 2006 and 2007. Determination of the profitability and feasibility of woven fabric in this study showed that a grower can obtain a higher net present value of cumulative net returns of $\$ 13,566 \mathrm{ha}^{-1}$ by the end of the seventh year by investing in woven fabric due to enhanced fruit yields, but must also invest $\$ 4332$ $\mathrm{ha}^{-1}$ more during the first four years of establishing a sweet cherry orchard to receive that profit. In conclusion, woven fabric is a profitable and sustainable in-row ground management alternative to herbicide strip for orchards over the long run.

\section{REFERENCES}

[1] Geldart, H.G. (1994) The impact of replant problems on the economics of high density apple plantings. Acta Horticulturae, 363, 11-18.

[2] Derr, J.F. (2001) Biological assessment of herbicide use in apple production. II. Estimated impacts following loss of specific herbicides. HortTechnology, 111, 20-25.

[3] Johnson, D.S. and Samuelson, T.J. (1990) Short-term effects of changes in soil management and nitrogen fertileizer application on "Bramley's Seedling" apple trees: II. Effects on mineral composition and storage quality of fruit. The Journal of Horticultural Science \& Biotechnology, 65, 495-502.

[4] Stevenson, D.S. and Neilsen, G.H. (1990) Nitrogen additions and losses to drainage in orchard type irrigated lysimeters. Canadian Journal of Soil Science, 70, 11-19. doi:10.4141/cjss90-002

[5] Merwin, I.A., Ray, J.A., Steenhuis, T.S. and Boll, J. (1996) Ground cover management systems influence fungicide and nitrate-N concentrations in leachate and runoff from a New York apple orchard. Journal of American Society for Horticultural Science, 121, 249-257.

[6] Shribbs, J.M. and Skroch, W.A. (1986) Influence of 12 ground cover systems on young "Smoothee Golden Delicious" apple trees: I. Growth. Journal of American Society for Horticultural Science, 111, 525-528.

[7] Parker, M.L. and Hull, J. (1993) Orchard floor management affects cherry tree growth and moisture utilization. Acta Horticulturae, 343, 201-213.

[8] Elmore, C.L., Merwin, I. and Cudney, D. (1997) Weed management in tree fruit, nuts, citrus and vine crops. In: McGiffen, M.E., Ed., Weed Management in Horticultural Crops, ASHS Press, Alexandria, 17-29.

[9] Glover, J.D., Reganold, J.P. and Andrews, P.K. (1999) Systematic method for rating soil quality of conventional, organic, and integrated apple orchards in Washington State. Agriculture, Ecosystems \& Environment, 80, 29-45. doi:10.1016/S0167-8809(00)00131-6

[10] Mäge, F. (1982) Black plastic mulching, compared to other orchard soil management methods. Scientia Horticulturae (Amsterdam), 16, 131-136.

[11] Lipecki, J. and Berbec, S. (1997) Soil management in perennial crops: Orchards and hop gardens. Soil and Tillage Research, 43, 169-184. 


$$
\text { doi:10.1016/S0167-1987(97)00039-1 }
$$

[12] Neilsen, G.H., Hogue, E.J., Forge, T. and Neilsen, D. (2003) Mulches and biosolids affect vigor, yield, and leaf nutrition of fertigated high density apple. HortScience, 38, 41-45.

[13] Stojanowska, J. (1994) Influence of mulching with perforated black foil on growth and bearing of cherry trees. Journal of Fruit and Ornamental Plant Research, 2, 1-7.

[14] Neilsen, G.H., Hogue, E.J., Forge, T. and Neilsen, D. (2003) Surface application of mulches and biosolids affect orchard soil properties after 7 years. Canadian Journal of Soil Science, 83, 131-137. doi:10.4141/S02-034

[15] Mehlich, A. (1984) Mehlich 3 soil test extractant: A modification of Mehlich 2. Communications in Soil Science and Plant Analysis, 15, 1409-1416. doi:10.1080/00103628409367568

[16] Khan, S.A., Mulvaney, R.L. and Hoeft, R.G. (2001) A simple soil test for detecting sites that are nonresponsive to nitrogen fertilization. Soil Science Society of America Journal, 65, 1751-1760. doi:10.2136/sssaj2001.1751

[17] Gavlak, R.G., Horneck, D.A. and Miller, R.O. (1994) Plant, soil and water reference methods for the western region. University of Alaska, Fairbanks.

[18] Watson, M.E. and Brown, J.R. (1998) $\mathrm{pH}$ and lime requirement. In: Brown, J.R., Ed., Recommended Chemical Soil Test Procedures for the North Central Region. NCR Research Publication, Columbia, 13-16.

[19] Combs, S.M. and Nathan, M.V. (1998) Soil organic matter. In: Brown, J.R., Ed., Recommended Chemical Soil Test Procedures for the North Central Region. NCR Re- search Publication, Columbia, 53-58.

[20] Oregon State University Extension Service. (2007) 2007 Wasco County sweet cherry production results. http://extension.oregonstate.edu/wasco/horticulture/Orcha rd\%20Economics/documents/2007Productionrevised.pdf

[21] Seavert, C.F., Hinman, H. and Teegerstrom, T. (2008) Agriculture's profitability tool (AgProfit ${ }^{\mathrm{TM}}$ ) http://agtools.org

[22] Yin, X.H., Seavert, C.F., Núñez-Elisea, R., Turner, J. and Cahn, H. (2007) Effects of polypropylene groundcover on soil nutrient availability, sweet cherry nutrition, and cash costs and returns. HortSciecne, 42, 147-151.

[23] Leece, D.R. (1975) Diagnostic leaf analysis for stone fruit. Australian Journal of Experimental Agriculture and Animal Husbandry, 15, 118-122. doi:10.1071/EA9750118

[24] Victoria State Department of Primary Industries (1995) Orchard nutrition 2: Soil and leaf analysis. Department of Primary Industries, Melbourne.

[25] Núñez-Elisea, R., Cahn, H., Caldeira, L. and Seavert, C.F. (2005) Polypropylene row covers greatly enhance growth and production of fourth-leaf sweet cherry trees. HortScience, 40, 1129.

[26] Thompson, J. (2006) Fruit physiological disorders: Stone fruit.

http://postharvest.ucdavis.edu/Produce/Disorders/stone/st onesurface.shtml

[27] Patten, K.D., Patterson, M.E. and Kupferman, E. (2007) Reducing surface pitting in sweet cherries. http://postharvest.tfrec.wsu.edu/pgDisplay.php?article=N $\underline{1 \mathrm{I} 2 \mathrm{C}}$ 